\title{
SELECTION OF ENTOMOPATHOGENIC NEMATODES AGAINST DALACA PALLENS (LEPIDOPTERA: HEPIALIDAE)
}

\author{
Alexis Maldonado ${ }^{1}$, Loreto Merino ${ }^{1}$, and Andrés France ${ }^{1 *}$
}

Dalaca pallens (Blanchard) is a pest with great impact on grassland production in Chile. The objective of this research was to evaluate the use of entomopathogenic nematodes (EPN) against D.pallens larvae. Twenty EPN isolates, collected along Chile, were used for nematode selection. The experimental unit consisted of five 50-mL plastic vials filled with Nothofagus dombeyi sawdust and inoculated with 40 dauers per vial. The experimental design was a completely randomized with four replicates per treatment. The results showed that isolate QU N3 (Steinernema australe) and QU N13 (Steinernema unicornum) produced the highest mortality, with 100 and $95 \%$ respectively and no differences $(\mathrm{P}<0.001)$ between both. Later, these two isolates were used to calculate the lethal concentration $\left(\mathrm{LC}_{50}\right.$ and $\left.\mathrm{LC}_{90}\right)$. Concentrations of $0,10,20,30$, 40 , and 50 dauers per $50-\mathrm{mL}$ plastic vials filled with Nothofagus sawdust were evaluated. Then, a single larva of $D$.pallens was added to each vial and incubated for $13 \mathrm{~d}$. The results showed that $\mathrm{LC}_{50}$ and $\mathrm{LC}_{90}$ were equivalent to 14 and 39 dauers $\mathrm{mL}^{-1}$ for isolate QU N3, while for isolate QUN13 these figures were 14 and 48 dauers $\mathrm{mL}^{-1}$. Consequently, there are native isolates of EPN with the ability to control $D$. pallens larvae, which require future test under field conditions.

Key words: Biological control, Steinernema australe, Steinernema unicornium, lethal concentration.

$D$ alaca pallens (Blanchard) (Lepidoptera: Hepialidae) is an economically important pest, listed as primary pest that justify control measures in the country (Klein and Waterhouse, 2000). The larvae cause significant damage in natural, sowed and regenerated pastures. A density of 50 third stage larvae $\mathrm{m}^{-2}$ can consume completely the pastures, by eating leaves and stems during the day and roots at night, leaving the soil completely uncovered (Artigas, 1994). Besides, it also affects blueberries, raspberries, myrtle, and forest species like eucalyptus during establishment. The pest is spread

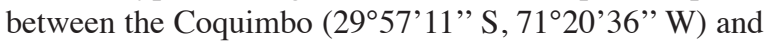
General Carlos Ibáñez del Campo Regions (45³4'0” S, $72^{\circ} 4^{\prime} 0$ ' W) (Artigas, 1994). Thus, 742537 ha of pastures are threaten annually and 250000 ha are effectively damaged (Neumann et al., 2007). Currently, the control of $D$. pallens larvae is done with chemical insecticides, which are not specific and damage beneficial arthropods, especially predators such as spiders and beetles (Pereira et al., 2008), leading to the elimination of natural enemies and eventually the increasing of $D$. pallens population on the pasture.

Entomopathogenic nematodes (EPN) of the families Steinernematidae and Heterorhabditidae are organisms that establish a symbiotic association with specific

${ }^{1}$ Instituto de Investigaciones Agropecuarias INIA, Casilla 426, Chillán, Chile. *Corresponding author (afrance@inia.cl).

Received: 29 October 2011.

Accepted: 17 May 2012. bacteria, belonging to the genus Xenorhabdus and Photorhabdus, respectively (Emelianoff et al., 2007). These nematodes search actively for the larvae in the soil by following several physical and chemical cues emitted by the host (Ramos-Rodríguez et al., 2007). The nematodes enter to the host through its natural openings (mouth, anus, and spiracles), and release a symbiotic bacteria, carried on a ventricular portion of the intestine, into the insect hemocoel. Then, the bacteria multiply and cause a general septicemia, ending in the insect death 24 to $48 \mathrm{~h}$ after infection (Kaya and Stock, 1997; Griffin et al., 2005).

In Chile, the Insect Pathology Program of Instituto de Investigaciones Agropecuarias (INIA) has been prospecting systematically the country, searching for EPN and demonstrating the presence of Steinernema and Heterorhabditis in Chilean soils (Edgington et al., 2010). Therefore, the objectives of this research were to select native isolates of EPN to control Dalaca pallens larvae, to establish lethal concentrations ( $\mathrm{LC}_{50}$ and $\mathrm{LC}_{90}$ ), lethal time ( $\mathrm{TL}_{50}$ and $\mathrm{TL}_{90}$ ) and to study the foraging strategy of the most effective isolates.

\section{MATERIALS AND METHODS}

\section{Nematode rearing}

A total of 20 isolates from the EPN collection of INIA, collected throughout Chile by a Darwin project (Edgington et al., 2010) were used for isolate selection. The nematodes were reared in vivo with Galleria mellonella 
larvae (Bedding and Akhurst, 1975). Fifty larvae were placed inside a $15-\mathrm{cm}$ diameter Petri dish lining with Whatman filter paper $\mathrm{N}^{\circ} 1$, then a concentration of 40 nematode juveniles per larvae were added with a micropipette (Kaya and Stock, 1997). The plates were incubated in darkness and a temperature of $15 \pm 2{ }^{\circ} \mathrm{C}$ until larvae death (Lacey and Shapiro-Ilan, 2008). The $G$. mellonella cadavers were transferred to 9-cm Petri dishes containing $10 \mathrm{~mL}$ of plaster; to allow a solid surface for nematode movement and the absorption of debris as the larvae corpse decompose (Lindegren et al., 1993). These dishes were placed inside a $12-\mathrm{cm}$ Petri plates that contain $25 \mathrm{~mL}$ of sterile water, where were collected the dauer nematodes that escape from the G. mellonella cadaver. The nematodes were collected daily, washed with tap water, counted and stored at $10 \pm 2{ }^{\circ} \mathrm{C}$, in plastic containers with tap water. The suspension was bubbling permanently (Realpe et al., 2007) with a diaphragm pump for oxygenation, until used in the bioassays.

\section{Collection of Dalaca pallens larvae}

The larvae of $D$. pallens were obtained by digging a pasture of Trifolium repens and Festuca arundinacea, located at the INIA experimental station Remehue (40 $31^{\prime} 65^{\prime}$ ' S, 7304'97" W), Osorno. Larvae were transported to the lab in plastic containers with Nothofagus sawdust as substrate and moistened with distilled water. Then, the larvae were stored individually in conical flasks and observed for $20 \mathrm{~d}$ to eliminate sick larvae. The larvae were classified according to their weight and diameter of the head capsule.

\section{Entomopathogenic nematode screening}

Twenty isolates of EPN were evaluated on D. pallens larvae as screening. Individual larvae of $0.14 \pm 0.05 \mathrm{~g}$ and $4 \mathrm{~mm}$ in diameter of cephalic capsule were placed inside of $50 \mathrm{~mL}$ conical plastic vial, filled with $30 \mathrm{~g}$ of pasteurized 40:60 Nothofagus sawdust and organic soil. Then, $3 \mathrm{~mL}$ of sterile water with 40 nematode dauers were added into each vial. The control treatment was supplied only with water. The larvae were fed daily with two leaves of fresh white clover. The experiment was incubated inside chambers at $15 \pm 2{ }^{\circ} \mathrm{C}$ and darkness (Allan et al., 2002), until the first treatment reached $100 \%$ of mortality.

Larva mortality was assessed every $24 \mathrm{~h}$, the criteria was to consider a dead larva those that did not move or response after brushing. Dead larvae were transferred to a moist chamber made of Petri dish lined with filter paper Whatman $\mathrm{N}^{\circ} 1$, moistened with distilled water and incubated at $15 \pm 2{ }^{\circ} \mathrm{C}$ until the emergence of the nematodes.

The experimental design was completely randomized, with 21 treatments, each treatment has five replicates and the experimental unit consisted of four conical vials with one larva of $D$.pallens each. The results were expressed as percentage of mortality; data were transformed to arcsine to homogenize the variances previous to the ANOVA. Values of 0 or $100 \%$ were corrected according to the formulas $(1 / 4 \times N)$ and $(100-1 / 4 \times N)$, respectively, where $\mathrm{N}=$ number of samples used (Campbell and Wraight, 2007). Data were subjected to ANOVA and lately the means were compared using Fisher's protected test with $95 \%$ of confidence. The analyses were performed with the statistical program Statistix, version 8.0 (Analytical Software, Tallahassee, Florida, USA).

\section{Study of the CL and TL}

Isolates that produced about $90 \%$ mortality in the previous trial were used to determine the lethal concentration of $50 \%\left(\mathrm{LC}_{50}\right)$ and $90 \%\left(\mathrm{LC}_{90}\right)$ of the D. pallens population, a $3 \mathrm{~mL}$ distilled water containing $0,10,20,30,40$, or 50 nematode dauers were used as inoculums and each added to $50 \mathrm{~mL}$ conical vials filled with the sawdust soil mixture mentioned above. Then, a single larva of D. pallens $(0.14$ $\pm 0.05 \mathrm{~g}$ and $4 \mathrm{~mm}$ of diameter head capsule) was added to each vial. The vials were incubated in a dark chamber at $15 \pm 2{ }^{\circ} \mathrm{C}$ and the larvae were fed daily with two leaves of fresh white clover. Evaluation consisted in larvae mortality assessed every $24 \mathrm{~h}$; the criteria to consider a dead larvae were the same described above. The dead larvae were incubated in a moist chamber made of Petri dish lined with filter paper Whatman $\mathrm{N}^{\circ} 1$, distilled water and temperature of $15 \pm 2{ }^{\circ} \mathrm{C}$, until the emergence of dauers. The trial was incubated until the first treatment reached $100 \%$ mortality. The results were subjected to regression analysis of nematode concentration vs. larvae mortality.

The experimental design was a completely randomized, were each experimental unit consisted of seven conical vials with a single larva of $D$. pallens inside of each vial, and four replicates per each treatment. The TL 50 and TL 90 was obtained directly from the linear regressions, while the $\mathrm{LC}_{50}$ and $\mathrm{LC}_{90}$ were estimated through regression analysis and then interpolated from the probit transformations (Fry, 1993).

In addition, we calculated chi-square statistic to determine the goodness of fit of the model to the experimental data. Concentrations of the selected isolates were compared through the regression slopes, obtained from each replicate, and using the Student's t-test with a confidence level of $95 \%$. The analyses were performed with the Minitab program version 15 (Minitab, State College, Pennsylvania, USA).

\section{RESULTS AND DISCUSSION}

\section{Entomopathogenic nematode screening}

Nineteen isolates out of 20 were pathogenic to larvae of D. pallens, causing different mortality rates. The dead larvae got a soft consistency and a yellow-brown to black color, characteristic of larvae killed by bacteria of the genus Xenorhabdus (Koppenhöfer, 2007). The control 
treatment did not show mortality during the course of the bioassay. Isolate QU-N3 was similar to QU-N13 (P $<0.001$ ), both reaching $95 \%$ of mortality (Figure 1) and were different to the rest of the isolates and the control. Koppenhöfer and Fuzy (2003) noted that differences in the pathogenicity of dauers can be attributed to their foraging strategy, the responsiveness of the host immune system, the pathogenicity of the symbiotic bacteria and the number of bacterial cells transported by the dauers. Furthermore, Koppenhöfer and Kaya (1999) have reported that Steinernema dauers can carry different amounts of bacterial cells in their intestines. For example, the species S. scapterisci contains a small amount of bacterial cells, instead the species $S$. carpocapsae contains a large number, causing a higher pathogenicity but at the expense of lower survival in the environment (Emelianoff et al., 2007). Isolates that had a zero or low value of mortality (Table 1) could be influenced by the immune response mechanisms of the insects, both humoral and cellular, such as encapsulation and melanization of nematodes, preventing the release of bacteria into the insect hemolymph and thereby the larvae septicemia (Alves, 1998). Heterorhabditis bacteriophora has a major tendency to be encapsulated within Acheta domesticus larvae, while $S$. scapterisci does not have this immune response in the same host (Lewis et al., 2006). Thus, some species of Steinernema secreted glycoproteins, which inhibit the prophenoloxidase enzyme that acts causing the encapsulation of parasites (Li et al., 2009).

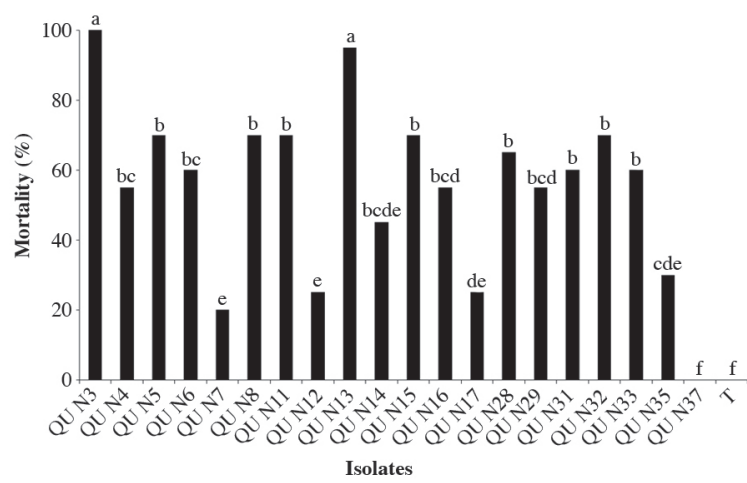

Different letters in bars indicate difference in treatments according Fischer protected test (P $\leq 0.05$ ) (critical value for comparison: 21.093).

Figure 1. Mortality of Dalaca pallens larvae inoculated with different isolates of entomopathogenic nematodes. Evaluation after $15 \mathrm{~d}$ incubation.

Table 1. Regression slopes of mortality and lethal concentration $\mathbf{5 0 \%}$ $\left(\mathrm{LC}_{50}\right)$ and $90 \%\left(\mathrm{LC}_{90}\right)$ of two isolates of Steinernema spp. on Dalaca pallens larvae.

\begin{tabular}{lccc}
\hline Isolate & Slope & LC $_{50}$ dauers $\mathrm{mL}^{-1}$ & $\mathrm{LC}_{90}$ dauers $\mathrm{mL}^{-1}$ \\
\hline QU N3 & $4.99 \mathrm{NS}$ & $14(6 \pm 20)$ & $39(35 \pm 54)$ \\
$\begin{array}{l}\text { (Steinernema australe) } \\
\text { QU N13 }\end{array}$ & 4.06 & $14(3 \pm 20)$ & $48(38 \pm 60)$ \\
(Steinernema unicornum) & & & \\
\hline
\end{tabular}

$\mathrm{LC}_{50}$ and $\mathrm{LC}_{90}$ : Concentration for killing $50 \%$ and $90 \%$ of the larvae population treated. NS: non significant according to the Student's t-test.
Isolates QU-N3 and QU-N13 correspond to two new species identified recently in Chile as Steinernema australe (Edgington et al., 2009a) and Steinernema unicornum (Edgington et al., 2009b), respectively. QU N3 was obtained from a sample collected in the Isla Magdalena National Park (44³6'42'" S, 72 51 ' 11 ' W), characterized by moist, sandy loam texture and $\mathrm{pH}$ 5.3. While the QUN13 was found in 52 soil samples along Chile, from 33 to $51^{\circ} \mathrm{S}$ lat, suggesting a better adaptation to different environments. However, the nematode characteristics, both biological and ecological, and their relationships with the symbiotic bacteria need future studies.

\section{Study of the CL and TL}

After $72 \mathrm{~h}$ incubation the infected larvae die and took the color and consistency characteristic for the EPN infection; described in the first trial. After $4 \mathrm{~d}$ dauers start emerging from the dead larvae; this process did not differ from other Steinernema species (Koppenhöfer, 2007). At the same time, the control treatment did not show mortality. After $13 \mathrm{~d}$ post inoculation the first isolation (QU-N3) reached $100 \%$ of larvae mortality, at the concentration of 50 dauers $\mathrm{mL}^{-1}$. The probit analysis (Table 1 ) showed $\mathrm{LC}_{50}$ and $\mathrm{LC}_{90}$ values of 14 and 39 dauers $\mathrm{mL}^{-1}$, respectively. While for isolate QU-N13 these lethal concentrations were 14 and 48 dauers $\mathrm{mL}^{-1}$ (Table 1). Consequently, both isolates required the same concentration of dauers to eliminate $50 \%$ of the larvae population, and a difference of nine dauers to eliminate $90 \%$ of the treated population (Table 1). Furthermore, slope analysis indicated no difference between both isolates $(\mathrm{P}=0.932)$. The goodness of fit test suggests that both isolates adjust properly to the regression curve $\left(\mathrm{X}^{2}=2.476, \mathrm{P}=0.480\right.$ and $\mathrm{X}^{2}=0.903, \mathrm{P}$ $=0.826$, respectively).

The curve of mortality over time was linear, then $\mathrm{TL}_{50}$ and $\mathrm{TL}_{90}$ were interpolated directly from the regressions, indicating that dauer concentration was inversely proportional to lethal time (Figure 2). Besides, both isolates have similar time to reach $\mathrm{LT}_{50}$ for the different concentrations (Table 2). However, mortality observed in lab trials rarely is coincident with the values obtained under field conditions, where the influence of

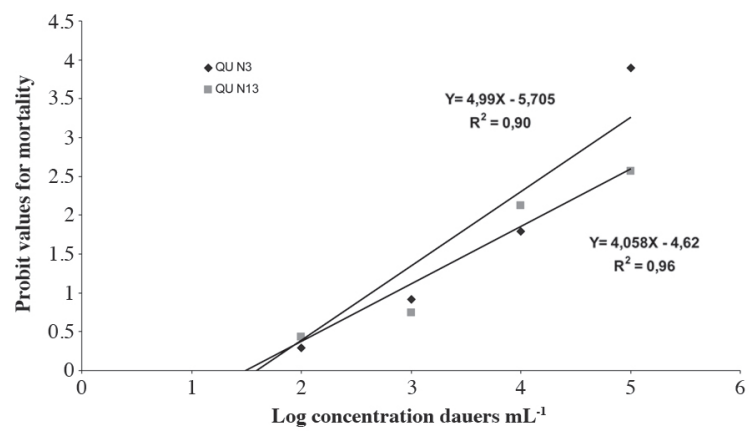

Figure 2. Larvae mortality of Dalaca pallens after $13 \mathrm{~d}$ of treated with different concentrations of entomopathogenic nematodes. 
soil chemistry and physical characteristics, competition with other microorganisms in addition to environmental conditions (Alves, 1998), reduces the amount of dauers reaching an insect.

Table 2. Lethal times (LT) for different concentrations of Steinernema spp. dauers (QU-N3 and QU-N13) on Dalaca pallens larvae.

\begin{tabular}{cllr}
\hline $\begin{array}{l}\text { Concentration } \\
\left(\text { dauers } \mathrm{mL}^{-1}\right)\end{array}$ & Isolate & $\mathrm{LT}_{50}(\mathrm{~d})$ & \multicolumn{1}{c}{$\mathrm{LT}_{90}(\mathrm{~d})$} \\
\hline \multirow{2}{*}{10} & QU N3 (S. australe $)$ & 11 & 25 \\
& QU N13 (S. unicornum $)$ & 13 & 28 \\
20 & QU N3 & 10 & 21 \\
& QU N13 & 10 & 20 \\
30 & QU N3 & 8 & 15 \\
& QU N13 & 8 & 17 \\
40 & QU N3 & 7 & 16 \\
& QU N13 & 6 & 13 \\
50 & QU N3 & 6 & 13 \\
& QU N13 & 5 & 11 \\
\hline
\end{tabular}

\section{CONCLUSIONS}

There are native entomopathogenic nematodes in Chile with the ability to parasitize Dalaca pallens larvae. Thus, two isolates of Steinernema (S. austral and S. unicornum) were able to cause above $90 \%$ of mortality. Also, the lethal concentrations and lethal time values were calculated and their ranges were appropriate for the control of Dalaca pallens larvae, values similar to other Steinernema species. Thus, both isolates have the potential for field control of Dalaca pallens larvae, facilitated by the food behavior of this species.

\section{Selección de nematodos entomopatógenos para el} control de Dalaca pallens (Lepidóptera: Hepialidae). Dalaca pallens (Blanchard) es considerada una de las plagas de mayor incidencia para la producción de las praderas en Chile. El objetivo de esta investigación fue la selección de aislamientos nativos de nematodos entomopatógenos (EPN) para el control de larvas de $D$. pallens. Se utilizaron 20 aislamientos nativos de EPN, para cada uno se inocularon 40 dauers por frascos cónicos con aserrín de Nothofagus dombeyi, y se agregó una larva de $D$. pallens de cuarto instar. Luego, se incubaron a $15{ }^{\circ} \mathrm{C}$ y oscuridad y se registró la mortalidad diaria. Se realizaron cuatro repeticiones por tratamiento y la unidad experimental fue de cinco frascos. Los resultados mostraron que el aislamiento QU N3 de Steinernema australe alcanzó el $100 \%$ de mortalidad a los 15 días de incubación, sin mostrar diferencias $(\mathrm{P}<0,001)$ con el tratamiento QU N13 (Steinernema unicornum), el cual alcanzó un 95\%. Para el cálculo de la concentración letal (CL50 y CL90) se usaron los dos aislamientos mencionados, y se evaluaron concentraciones de $0,10,20,30,40$ y 50 dauers por frasco que contenían una larva de $D$. pallens de cuarto instar. Para el aislamiento QU N3 la CL 50 y CL90 fue de 14 y 39 dauers $\mathrm{mL}^{-1}$, a los 13 d de incubación, mientras que para QU N13 estos valores fueron de 14 y 48 dauers $\mathrm{mL}^{-1}$. En conclusión, existen aislamientos nativos de EPN con habilidad para parasitar larvas de $D$. pallens, los cuales necesitan ser evaluados en condiciones de campo.

Palabras clave: control biológico, Steinernema australe, Steinernema unicornium, concentración letal.

\section{LITERATURE CITED}

Alves, S. 1998. Patologia e controle microbiano: vantagens e desvantagens. p. 21-34. In Controle microbiano de insectos. $2^{\mathrm{a}}$ ed Fundação de Estudios Agrários Luiz de Queiroz (FEALQ), Sao Paulo, Brasil.

Allan, R., Q. Wang, A. Jiménez-Pérez, and L. Davis. 2002. Wiseana copularis larvae (Hepialidae: Lepidoptera): laboratory rearing procedures and effect of temperature on survival. New Zealand Journal of Agricultural Research 45:71-75.

Artigas, J. 1994. Entomología económica. Insectos de interés agrícola, forestal, médico y veterinario (nativos, introducidos y susceptibles de ser introducidos). Volumen II. Ediciones Universidad de Concepción, Concepción, Chile.

Bedding, R., and R. Akhurst. 1975. A simple technique for the detection of insect parasitic rhabditid nematodes in soil Nematologica 21:109-110.

Campbell, J., and S. Wraight. 2007. Experimental design: statistical considerations and analysis. p. 37-69. In Lacey, L., and H. Kaya (eds.) Field manual of techniques in invertebrate pathology. $2^{\text {nd }}$ ed. Springer, Dordrecht, The Netherlands.

Edgington, S., A.G. Buddie, D. Moore, A. France, L. Merino, L.M. Tymo, and D.J. Hunt. 2010. Diversity and distribution of entomopathogenic nematodes in Chile. Nematology 12:915-928.

Edgington, S., A.G. Buddie, L.M. Tymo, A. France, L. Merino, and D.J. Hunt. 2009b. Steinernema unicornum sp. n. (Panagrolaimomorpha: Steinernematidae), a new entomopathogenic nematode from Tierra del Fuego, Chile. Journal of Nematode Morphology and Systematics 12:113-131.

Edgington, S., A.G. Buddie, L.M. Tymo, D.J. Hunt, K. Nguyen, A. France, L. Merino, and D. Moore. 2009a. Steinernema australe $\mathrm{n}$. sp. (Panagrolaimomorpha: Steinernematidae), a new entomopathogenic nematode from Isla Magdalena, Chile. Nematology 11:699-717.

Emelianoff, V., M. Sicard, N. Le Braun, C. Moulia, and J-B. Ferdy. 2007. Effect of bacterial symbionts Xenorhabdus on mortality of infective juveniles of two Steinernema species. Parasitology Research 100:657-659.

Fry, J. 1993. Curved regression lines. p. 105-122. In Biological data analysis: a practical approach. IRL Press/Oxford University Press, New York, USA.

Griffin, C., N. Boemare, and E. Lewis. 2005. Biology and behaviour. p. 47-59. In Grewal, P., R.-U. Ehlers, and D. Shapiro-Ilan (eds.) Nematode as biocontrol agents. CABI Publishing, Wallingford, UK.

Kaya, H., and S. Stock. 1997. Techniques in insect nematology. p. 281-324. In L. Lacey (ed.) Biological techniques: Manual of techniques in insect pathology. Academic Press, Millbrae, California, USA.

Klein, C., and D. Waterhouse. 2000. Distribución e importancia de los artrópodos asociados a la agricultura y silvicultura en Chile. Australian Centre for International Agricultural Research, Canberra, Australia.

Koppenhöfer, A. 2007. Nematodes. p. 249-264. In Lacey, L., and H. Kaya (eds.) Field manual of techniques in invertebrate pathology: Application and evaluation of pathogens for control of insects and other invertebrate pest. $2^{\text {nd }}$ ed. Kluwer Academic Publishers Dordrecht, The Netherlands.

Koppenhöfer, A., and E. Fuzy. 2003. Steinernema scarabaei for the control of white grubs. Biological Control 28:47-59. 
Koppenhöfer, A., and H. Kaya. 1999. Ecological characterization of Steinernema rarum. Journal of Invertebrate Pathology 73:120128.

Lacey, L., and D. Shapiro-Ilan. 2008. Microbial control of insect pest in temperate orchard systems: Potential for incorporation into IPM. Annual Review of Entomology 53:121-144.

Lewis, E., J. Campbell, C. Griffin, H. Kaya, and A. Peters. 2006. Behavioral ecology of entomopathogenic nematodes. Biological Control 38:66-79.

Li, X., E. Cowles, R. Cowles, R. Gaugler, and D. Cox-Foster. 2009. Characterization of immunosuppressive surface coat proteins from Steinernema glaseri that selectively kill blood cells in susceptible hosts. Molecular Biochemistry and Parasitology 165:162-169.

Lindegren, J.E., K.A. Valero, and B.E. Mackey. 1993. Simple in vivo production and storage methods for Steinernema carpocapsae infective juveniles. Journal of Nematology 25:193-197.
Neumann, E., R. Olivares, G. Véliz, P. Sepúlveda, V. Ríos, y X.Arcos. 2007. VII Censo Nacional Agropecuario y Forestal: Resultados preliminares 2006-2007. Instituto Nacional de Estadística (INE), Santiago, Chile.

Pereira, C., E. Pereira, E. Cordeiro, T. Della, M. Tótola, and R. Guedes. 2008. Organophosphate resistance in the maize weevil Sitophilus zeamais: magnitude and behavior. Crop Protection 28:168-173.

Ramos-Rodríguez, O., J. Campbell, E. Lewis, D. Shapiro-Ilan, and S. Ramaswamy. 2007. Dynamics of carbon dioxide release from insects infected with entomopathogenic nematodes. Journal of Invertebrate Pathology 94:64-69.

Realpe, F., A. Bustillo, y J. López. 2007. Optimización de la cría de Galleria mellonella (L.) para la producción de nemátodos entomopatógenos parásitos de la broca del café. Cenicafé 58:142157. 